To Support Customers in Easily and Affordably Obtaining the Latest Peer-Reviewed Research, Receive a 20\% Discount on ALL Publications and Free Worldwide Shipping on Orders Over US\$ 295

\title{
Necessity of Paradigm Shift in Criminological Theorizing
}

Ajibade Ebenezer Jegede (Covenant University, Nigeria), Olusola Oyero (Covenant University, Nigeria), Nelson Okorie (Covenant University, Nigeria), Caleb Abiodun Ayedun (Covenant University, Nigeria) and Mofoluwake Ajayi (Covenant University, Nigeria)

Source Title: Encyclopedia of Criminal Activities and the Deep Web Copyright: (C) 2020 |Pages: 19

DOI: $10.4018 / 978-1-5225-9715-5 . \operatorname{ch} 014$

OnDemand PDF Download:

$\$ 30.00$

List Price: $\$ 37.50$

\section{Abstract}

The traditional linkage of defective educational acquisition and the propensity to engage in antisocial behaviours has been accentuated in criminological theory. However, current development in ICT environment preferred for spacelessness, timelessness with its unchanging requirement for ingenuity in the use and mastery of e-interaction has consistently queried the veracity of defective education and crime participation. A survey on cyber fraud conducted in Nigeria found out that the acquisition of requisite education is central to technology-driven crime participation and guarantees continual survival and career longevity in crime business. Consequently, this article analyses the necessity of educational acquisition for crime participation and further advocated for a paradigm shift to accommodate the changing trends in the education-crime symbiotic relationship in the ICT age. This is germane to criminology of ICT in capturing and mitigating the victimization that are contactable through participation in e-relationship.

Chapter Preview

$\underline{\text { Top }}$

\section{Introduction}

The triad of education, human development and socio-economic transformation or otherwise is central to the understanding of the processes involved in the workings of modern society. Inadvertently, the cyclical relationship existing between these three has been documented in research (Virginia, 2005; 27). Of recent, education was described as one of the accelerators of human, social and economic development (Ifenkwe, 2013:007). The importance of education 
remains unquantifiable across major indices of socio-economic development. Fundamentally, education promotes mastery of some certain procedures to the point where they become unconscious and automatic, it also permits the application of the procedures to structure information into conceptual knowledge that is used consciously and deliberately (Abadzi, 2006). These attributes when put together make education unique in its contributions to relational advancement globally.

Traditionally, education serves as a potent instrument for eliciting conformism to institutional rules and regulations and men in their various classes are socialized with the view of sustaining social stability and progress. However, in modern society, a subset of deliberate educational application tilts towards the retardation of development in the context of actions that are inimical to the overall interest of the generality. Few occurrences in the technological age attest to the fact that educational application is not uni-lineal in its consequences for socio-economic development. Of a truth, there is a dual application of educational inputs and with its negative connotations unabatedly becoming registerable in crime and in a gamut of other anti-social behaviours globally. The manifest function of education that is commonly ushering and sustaining this turn of event is not farfetched. At inception, the defect of working against the interest of significant individuals and favouring few others has been the bane of education. This was aptly described by Coffey (2001) as differential outcomes of education.

In educational acquisition, the key democratic ideals of liberty and equality have always been in conflict in a nation with acute capitalist acumen (Brantlinger, 2007). Explaining this in a concise manner, Deleuze and Guattari (1983) disclosed that the emergence of monopoly capitalism radically transformed the social world: it swept away traditional social forms, as economic forces bite deeply into the symbolic textures of society itself (cited in Elliot, 2014:255). This symptom of destabilization then became recordable in the negativity attendant to educational skill utilization. Noblit and Pink (1995) argue that whereas the original philosophy for schooling hinges on achieving consensual relationship among diversely attributed populace, recent experiences have clearly shown that schooling is consistently promoting opposition, resistance and conflict in its consequences for societal survival. Apart from the factor located in biasness and inferiority attendant of diverse mode of knowledge dissemination according to Bourdieu, (1984), the unraveling scenario in the information technology age has now shown that school dropout is no longer sufficient reason for youth crime participation in the modern era. More significantly is the continued access of the vast majority of people to e-technology gadgets with its concomitant transformation of a relationship into virtuality.

\title{
Complete Chapter List
}

\author{
Search this Book: \\ Reset \\ Dedication \\ View Full PDF \\ Table of Contents by Volume \\ View Full PDF \\ Table of Contents by Category \\ $\underline{\text { View Full PDF }}$
}


Preface

Mehdi Khosrow-Pour D.B.A.

View Full PDF

Acknowledgment

Mehdi Khosrow-Pour D.B.A.

View Full PDF

Chapter 1

Cybercrime (pages 1-22)

Poongodi Thangamuthu, Anu Rathee, Suresh Palanimuthu, Balamurugan Balusamy

Sample PDF

$\$ 37.50$

Chapter 2

Copyright (C) 1988-2020, IGI Global - All Rights Reserved 